\title{
Spatio-temporal variability of biophysical parameters of irrigated maize using orbital remote sensing
}

\section{Variabilidade espaço-temporal de parâmetros biofisícos do milho irrigado utilizando sensoriamento remoto orbital}

\author{
Taiara Souza Costa1*; Robson Argolo dos Santos²; Rosângela Leal Santos; \\ Roberto Filgueiras ${ }^{4}$; Fernando França da Cunha5; Anderson de Jesus Pereira6; \\ Rodrigo Amaro de Salles ${ }^{7}$
}

\section{Highlights}

Use of orbital remote sensing in irrigation management.

Estimation of dry biomass as a possibility of predicting final yield.

Spatio-temporal dynamics of actual crop evapotranspiration.

\begin{abstract}
This study proposes to estimate the actual crop evapotranspiration, using the SAFER model, as well as calculate the crop coefficient $(\mathrm{Kc})$ as a function of the normalized difference vegetation index (NDVI) and determine the biomass of an irrigated maize crop using images from the Operational Land Imager (OLI) and Thermal Infrared (TIRS) sensors of the Landsat- 8 satellite. Pivots 21 to 26 of a commercial farm located in the municipalities of Bom Jesus da Lapa and Serra do Ramalho, west of Bahia State, Brazil, were selected. Sowing dates for each pivot were arranged as North and South or East and West, with cultivation starting firstly in one of the orientations and subsequently in the other. The relationship between NDVI and the Kc values obtained in the FAO-56 report $\left(\mathrm{KC}_{\mathrm{FAO}}\right)$ revealed a high coefficient of determination $\left(\mathrm{R}^{2}=0.7921\right)$, showing that the variance of $\mathrm{KC}_{\mathrm{FAO}}$ can be explained by NDVI in the maize crop. Considering the center pivots

1 Student of the Master's Course of the Graduate Program in Agricultural Engineering, Universidade Federal de Viçosa, UFV, Viçosa, MG, Brazil. E-mail: taiarasouzacosta1@gmail.com

2 Student of the Doctoral Course of the Graduate Program in Agricultural Engineering, UFV, Viçosa, MG, Brazil. E-mail: argolo.agro@gmail.com

3 Profa Dra, Technology Department, Universidade Estadual de Feira de Santana, UEFS, BA, Brazil. E-mail: rosangela. leal@gmail.com

${ }^{4}$ Dr., Department of Agronomic Engineering, UFV, Viçosa, MG, Brazil. E-mail: betofilgueiras@gmail.com

${ }^{5}$ Prof., Department of Agronomic Engineering, UFV, Viçosa, MG, Brazil. E-mail: fernando.cunha@ufv.br

${ }^{6}$ Student of the Master's Course of the Irrigation and Drainage, Universidade Estadual Paulista, UNESP, São Paulo, SP, Brazil. E-mail: agroandersonn@gmail.com

7 Student of the Doctoral Course of the Phytotechnics, UFV, Viçosa, MG, Brazil. E-mail: rodrigoamarodesalles@gmail. com

* Author for correspondence
\end{abstract}

Received: Oct. 21, 2020 - Approved: May 03, 2021 
with different planting dates, the crop evapotranspiration $\left(E T_{c}\right)$ pixel values ranged from 0.0 to $6.0 \mathrm{~mm} \mathrm{~d}^{-1}$ during the phenological cycle. The highest values were found at 199 days of the year (DOY), corresponding to around 100 days after sowing (DAS). The lowest BIO values occur at 135 DOY, at around 20 DAS. There is a relationship between $\mathrm{ET}_{\mathrm{c}}$ and $\mathrm{BIO}$, where the $\mathrm{DOY}$ with the highest $\mathrm{BIO}$ are equivalent to the days with the highest $\mathrm{ET}_{\mathrm{c}}$ values. In addition to this relationship, $\mathrm{BIO}$ is strongly influenced by soil water availability.

Key words: Agrometeorological models. Irrigation management. Phenological cycle.

\section{Resumo}

Objetivou-se com o presente estudo estimar a evapotranspiração real da cultura por meio do modelo SAFER, calcular o Kc em função do NDVI e a biomassa da cultura do milho irrigado, utilizando para isso imagens dos sensores Operacional Land Imager (OLI) e Thermal Infrared Sensor (TIRS) do satélite Landsat-8. Foram selecionados os pivôs 21 ao 26 de uma fazenda comercial localizada nos municípios de Bom Jesus da Lapa e Serra do Ramalho, situadas no oeste do estado da Bahia, Brasil. As épocas de semeadura dentro dos pivôs são ordenadas em Norte e Sul ou Leste e Oeste, iniciando o cultivo primeiro em uma das orientações e posteriormente na outra. Verifica-se com base na relação entre NDVI e Kc $\mathrm{FAO}_{\text {' }}$ um alto valor do coeficiente de determinação $\left(R^{2}=0,7921\right)$, evidenciando que a variância do $\mathrm{Kc}_{\mathrm{FAO}}$ pode ser explicada pelo NDVI na cultura do milho. Considerando-se os pivôs centrais com diferentes datas de plantio, os valores dos pixels da $\mathrm{ET}_{\mathrm{c}}$ variaram de 0,0 a 6,0 $\mathrm{mm} \mathrm{d}^{-1}$ durante o ciclo fenológico. Os maiores valores foram encontrados para o DOY 199, correspondendo ao DAS em torno de 100 dias. Os valores mais baixos da BIO ocorrem aos 135 DOY em torno de 20 DAS. É observado que existe uma relação entre a $\mathrm{ET}_{\mathrm{c}}$ e BIO, os DOY mais elevados da BIO são equivalentes com os maiores valores de $\mathrm{ET}_{\mathrm{c}}$. Além desta relação, a BIO é fortemente influenciada pela disponibilidade hídrica no solo.

Palavras-chave: Ciclo fenológico. Manejo da irrigação. Modelos agrometeorológicos.

\section{Introduction}

Irrigation management consists of the application of water at the right time and in the necessary amount for the crop (Bernardo, Mantovani, Silva, \& Soares, 2019). Among the existing irrigation management methods, the weather-based approach is the most commonly used due to its easy execution and greater technical and economic viability (Althoff, Santos, Bazame, Cunha, \& Filgueiras, 2019; Santos, Venancio, Filgueiras, \& Cunha, 2020). In view of the importance of the crop coefficient $(\mathrm{Kc})$ for weather-based irrigation management, various studies have examined the modeling of this parameter as a function of the vegetation index and shown good results (Alface, Pereira, Filgueiras, \& Cunha, 2019), as it is estimated using real field conditions.

It is worth stressing, however, that weather-based management considers the irrigation amount to be applied equally across the cultivated area (Martins, Busato, Silva, Rodrigues, \& Reis, 2013). Therefore, studies that estimate the spatial and temporal variability of the actual crop evapotranspiration (ETC) are relevant and provide basis for applying irrigation at a variable rate, replacing the adequate amount of water. 
Agrometeorological models were thus developed for the spatial and temporal determination of $\mathrm{ET}_{\mathrm{c}}$ via orbital remote sensing techniques. A noteworthy example of such methods is the Simple Algorithm for Evapotranspiration Retrieving (SAFER) presented by Teixeira (2010). The technique consists of an easy-to-apply algorithm (Teixeira, 2010) with good results demonstrated in studies focusing on irrigation management In addition to the water demand, it also allows us to determine the daily increase in crop biomass (BIO). Knowing the $\mathrm{BIO}$ increase is important to predict the final yield of the crop, as done by Bastiaanssen and Ali (2003).

The above descriptions evidence the importance of knowing the spatio-temporal variability of crop parameters such as $\mathrm{ET}_{\mathrm{c}^{\prime}}$ $\mathrm{Kc}$ and the accumulated biomass increase in irrigated crops. On this basis, the present study was developed to estimate the $\mathrm{ET}_{c}$ using the SAFER model as well as calculate the Kc as a function of NDVI and the biomass of an irrigated maize crop using images from the Operational Land Imager (OLI) and Thermal Infrared (TIRS) sensors of the Landsat-8 satellite.

\section{Material and Methods}

The study site comprises center pivots of a commercial farm located in the municipalities of Bom Jesus da Lapa and Serra do Ramalho, west of Bahia State, Brazil. The municipality of Bom Jesus da Lapa is located by the coordinate pairs, with $\mathrm{X} 1$ : -42.90936 ; Y1: -12.68917 as the upper-left corner and X2: -43.70607; Y2: -13.87617 as the lower-right corner. The municipality of Serra do Ramalho is also delimited by the coordinate pairs, with $\mathrm{X}$ : $:-43.43047$; Y1: -13.18179 as the upperleft corner and X2: -43.93314; Y2: -13.80629 as the lower-right corner. Both municipalities adopt the WGS84 coordinate reference system.

The farm performs crop rotation under 30 center pivots. In this study, we worked with the maize crop (Figure 1). Considering the most consistent data and orbital images free of the presence of clouds, pivots 21 to 26 were selected, totaling six pivots. Pivots 21 to 25 have an area of 45 ha each and pivot 26 has an area of 33 ha. Sowing dates for each pivots are arranged as North and South or East and West, with cultivation starting firstly in one of the orientations (bands of the center pivots) and subsequently in the other (Table 1). 


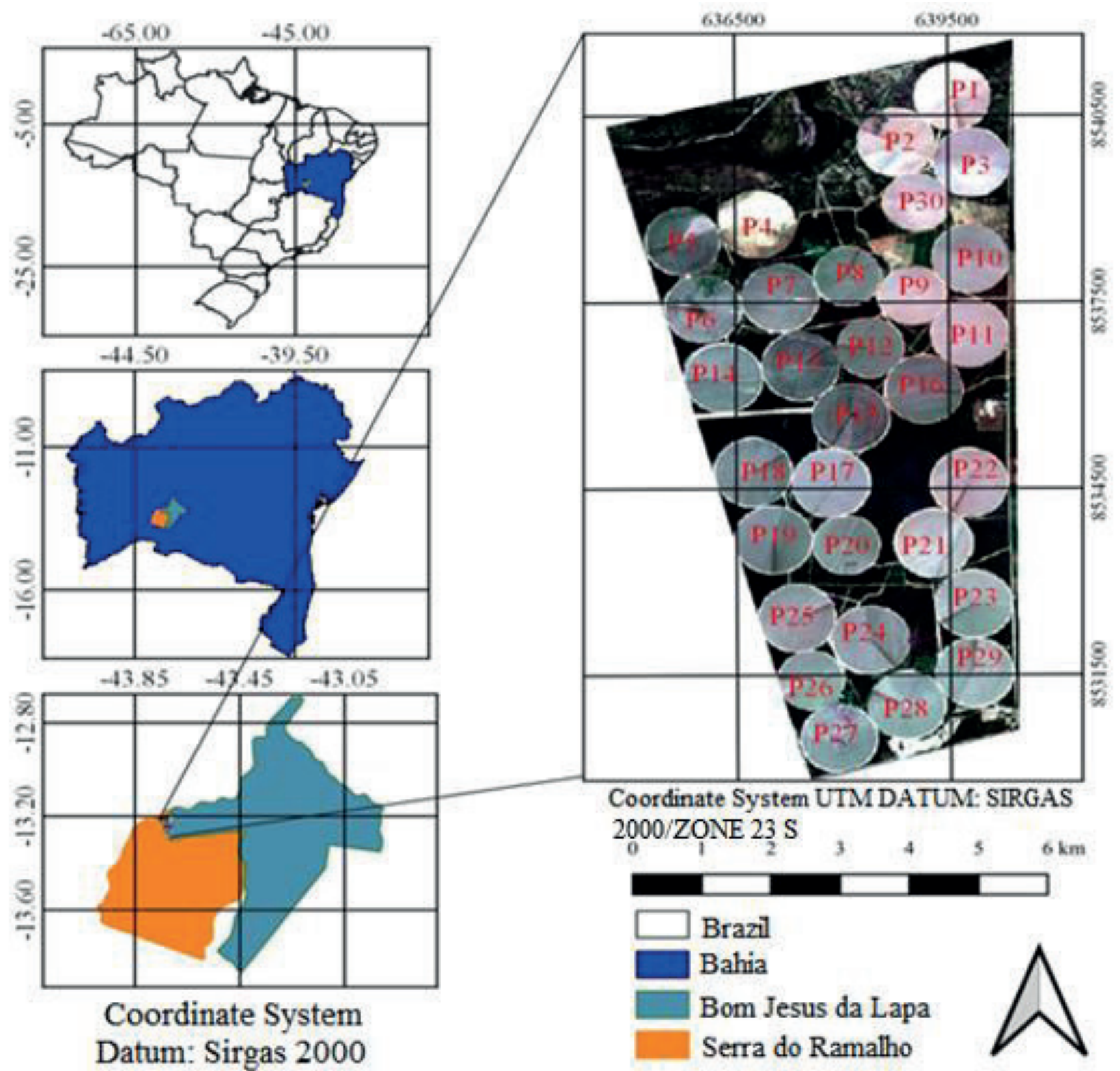

Figure 1. Geographic location of the study area indicating the municipalities covered, the state of Bahia and Brazil. 
To estimate the biophysical parameters of the area, eight images from the year 2014 (04/13/2014, 05/15/2014, 05/31/2014, 07/02/2014， 07/18/2014， 08/19/2014, 09/04/2014 and 09/20/2014) were acquired from the OLI and TIRS sensors of the Landsat- 8 satellite, with resolution of 30 and $100 \mathrm{~m}$, respectively, and Level-1 processing. These images were acquired on the Earth Explorer platform, available at http://earthexplorer.usgs. gov/ (United States Geological Survey [USGS], 2015). After the images were obtained, the pre-processing procedures were performed in QGis ${ }^{\circledR} 3.16$ software (QGIS Development Team [QGIS], 2015) for converting digital numbers to physical values and atmospheric correction. Atmospheric correction was achieved using the DOS 1 (Dark Object Subtraction) method and the Semi-Automatic Classification plugin (Congedo, 2016). Subsequently, the SAFER algorithm was run, in which the biophysical parameters that compose the ETc were calculated.

Table 1

Information regarding the cultivation of irrigated maize

\begin{tabular}{|c|c|c|c|c|c|c|}
\hline Pivot & PO & $\begin{array}{c}\text { Area } \\
\text { ha }\end{array}$ & $\mathrm{Cv}$ & Planting & El & $\frac{\mathrm{IA}}{\mathrm{mm}}$ \\
\hline 21 & Norte & 45 & 1 & $04 / 24 / 2014$ & 08/18/2014 & 392.48 \\
\hline 21 & Sul & 45 & 1 & $04 / 23 / 2014$ & 08/18/2014 & 371.65 \\
\hline 22 & Norte & 45 & 1 & $04 / 26 / 2014$ & 09/18/2014 & 520.15 \\
\hline 22 & Sul & 45 & 1 & $04 / 25 / 2014$ & $08 / 21 / 2014$ & 507.11 \\
\hline 23 & Norte & 45 & 1 & 04/17/2014 & $08 / 11 / 2014$ & 358.67 \\
\hline 23 & Sul & 45 & 1 & $04 / 28 / 2014$ & 08/09/2014 & 378.76 \\
\hline 24 & Oeste & 45 & 1 & $04 / 16 / 2014$ & 08/09/2014 & 526.12 \\
\hline 24 & Leste & 45 & 1 & 04/09/2014 & 08/10/2014 & 547.21 \\
\hline 25 & Norte & 45 & 2 & $04 / 04 / 2014$ & $07 / 28 / 2014$ & 434.41 \\
\hline 25 & Sul & 45 & 1 & 04/03/2014 & $07 / 28 / 2014$ & 453.01 \\
\hline 26 & Norte & 33 & 1 & $04 / 05 / 2014$ & 08/04/2014 & 460.48 \\
\hline 26 & Sul & 33 & 1 & 04/04/2014 & 08/02/2014 & 439.82 \\
\hline
\end{tabular}

PO - Planting orientation; Cv - Cultivar; El - End of irrigation; IA - irrigation amount applied in the cycle. 1- Dekalb 390 VT Pro 2 maize; 2- Dekalb 390 Conventional maize. 


\section{Actual crop evapotranspiration (ETC)}

To determine the ETc from the SAFER algorithm, it is necessary to calculate the biophysical parameters displayed below. The first biophysical parameter estimated in SAFER was the albedo at the top of the atmosphere ( $\alpha \mathrm{TOA}$ ) (Equation 1), which makes it possible to estimate the other parameters (Equations 2, 3, 4, 5 and 6) and subsequently ETc. From the $\alpha$ TOA, the surface albedo ( $\alpha s)$ was calculated using Equation 2. The weights adopted to determine $\alpha$ TOA were defined by the methodology of B. B. Silva et al. (2016).

$$
\begin{array}{r}
\alpha_{\mathrm{TOA}}=0.300 \rho_{2}+0.277 \rho_{3}+0.233 \rho_{4}+0.143 \rho_{5}+0.036 \rho_{6}+0.012 \rho_{7} \\
\alpha_{\mathrm{s}}=\alpha \times \alpha_{\mathrm{TOA}}+b
\end{array}
$$

where $\rho 2, \rho 3, \rho 4, \rho 5, \rho 6$ and $\rho 7$ are the surface reflectances of bands 2, 3, 4, 5, 6 and 7 (Equation 1); and $\alpha-0.7$ and b- 0.06 (Equation 2) are the regression coefficients (Vanhellemont \& Ruddick, 2014).

Surface temperature (Ts) was obtained using Equation 3. To calculate Tbri, band 10 (thermal) was used.

$$
\mathrm{T}_{\mathrm{s}}=1.11 \times \mathrm{T}_{\text {bri }}-31.89
$$

where $\rho 10$ is the thermal infrared band of the TIRS sensor of Landsat 8 satellite.

The normalized difference vegetation index (NDVI) is an indicator related to the status of the plant from the red and near-infrared reflectance. Higher NDVI values translate into larger amounts of chlorophyll and, consequently, a greater productive potential of the plant (Rissini, Kawakami, \& Genú, 2015). This index was calculated using Equation 4 (Rouse, Haas, Schell, \& Deering, 1974).

$$
\mathrm{NDVI}=\frac{\rho_{\text {nir }}-\rho_{\mathrm{r}}}{\rho_{\text {nir }}+\rho_{\mathrm{r}}}(4)
$$

where $\rho_{\text {nir }}$ is the reflectance in the near-infrared band (band 5); and $\rho r$ is the reflectance in the red band (band 4).

The evapotranspiration fraction (ETf) (Equation 5) was determined using the $\alpha s$, Ts and NDVI biophysical parameters data.

$$
\mathrm{ET}_{\mathrm{f}}=\exp \left[\mathrm{a}+\mathrm{b}\left(\frac{\mathrm{T}_{\mathrm{s}}}{\mathrm{as} \times \mathrm{NDVI}}\right)\right]
$$

where $a$ and $b$ are the regression coefficients obtained by the model of Teixeira (2010), which showed the respective values of 1.8 and -0.008 , adjusted for the semi-arid conditions of Brazil.

Subsequently, the reference evapotranspiration $\left(E T_{0}\right)$ in $\mathrm{mm} \mathrm{d}^{-1}$ was estimated by the FAO 56 Penman-Monteith method (Allen, Pereira, Raes, \& Smith, 1998), using daily weather data from the weather station located at the study site (Equation 6).

$$
\mathrm{ET}_{\mathrm{o}}=\frac{0.408 \Delta\left(\mathrm{R}_{\mathrm{N}}-\mathrm{G}\right)+\gamma\left(\frac{900}{\mathrm{~T}+273}\right) \mathrm{U}_{2}\left(\mathrm{e}_{\mathrm{s}}-\mathrm{e}_{\mathrm{a}}\right)}{\Delta+\gamma\left(1+0.34 \times \mathrm{U}_{2}\right)}
$$

where ETo is the reference evapotranspiration $\left(\mathrm{mm} \mathrm{d}^{-1}\right) ; \Delta$ is the slope of the vapor pressure curve $\left(\mathrm{kPa}^{\circ} \mathrm{C}^{-1}\right)$; $\mathrm{RN}$ is the net radiation at the crop surface ( $\left.\mathrm{MJ} \mathrm{m}^{-2} \mathrm{~d}^{-1}\right)$; $\mathrm{G}$ is the soil heat-flux density $\left(\mathrm{MJ} \mathrm{m} \mathrm{m}^{-2} \mathrm{~d}^{-1}\right) ; \mathrm{Y}$ is the psychrometric constant $\left(\mathrm{kPa}^{\circ} \mathrm{C}^{-1}\right) ; \mathrm{T}$ is the mean daily air temperature $\left({ }^{\circ} \mathrm{C}\right) ; U_{2}$ is the wind speed (daily mean) at a height of $2 \mathrm{~m}$; $\mathrm{e}_{\mathrm{s}}$ is the saturation vapor pressure $(\mathrm{kPa})$; and $\mathrm{e}_{\mathrm{a}}$ is the actual vapor pressure $(\mathrm{kPa})$.

From the $\mathrm{ET}_{\mathrm{o}}$ and $\mathrm{ET}_{\mathrm{f}}$ data, $\mathrm{ET}_{\mathrm{c}}$ was estimated in $\mathrm{mm} \mathrm{d}^{-1}$ using Equation 7.

$$
\mathrm{ET}_{\mathrm{c}}=\mathrm{ET}_{\mathrm{f}} \times \mathrm{ET}_{\mathrm{o}}(7)
$$




\section{Accumulated biomass (BIO)}

Knowing the $\mathrm{BIO}$ is fundamental to make rational use of plants and to monitor nutrient cycling. In addition to allowing the calculation of grain yield, this variable is important for planning the logistics, storage and marketing of the crop even before the harvest (Higuchi, Santos, Ribeiro, Minette, \& Biot, 1998). To determine the daily BIO increase, it was first necessary to determine the absorbed photosynthetically active radiation (APAR) by the crop (Bastiaanssen \& Ali, 2003) (Equation 8).

$$
\mathrm{APAR}=(1.26 \times \mathrm{NDVI}-0.16) \times\left(0.48 \times \mathrm{R}_{\mathrm{G}}\right)
$$

where $\mathrm{RG}$ is the daily solar radiation $\left(\mathrm{W} \mathrm{m}^{-2}\right)$; and NDVI is the normalized difference vegetation index.

Biomass production per unit area over time was calculated using the radiation model developed by Monteith (1972), according to Equation 9. The $\mathrm{BIO}$ variable represents how much biomass the plant added to its structure per day, in kilograms.

$$
\mathrm{BIO}=\varepsilon_{\max } \times \mathrm{ET}_{\mathrm{f}} \times \mathrm{APAR} \times 0.864
$$

where $\mathrm{BIO}$ is the total biomass accumulated in the day ( $\mathrm{kg} \mathrm{ha}^{-1} \mathrm{~d}^{-1}$; dry matter); $\varepsilon_{\max }$ is the maximum radiation use efficiency, which is $2.7 \mathrm{~g} \mathrm{MJ}^{-1}$ for the maize crop (Bastiaanssen \& Ali, 2003); 0.864 is the conversion factor that makes it possible to obtain biomass in $\mathrm{kg} \mathrm{ha}^{-1}$ (Teixeira, Scherer-Warren, Hernandez, Andrade \& Leivas, 2013); and APAR is the absorbed photosynthetically active radiation.

\section{Crop coefficient (Kc)}

From the $\mathrm{Kc}$ values obtained in the FAO-56 report, here called $\mathrm{Kc}_{\mathrm{FAO}^{\prime}}$ and the NDVI values for each date of the images under study, expressed as a function of the crop cycle, a simple linear regression model (Equation 10) was fitted to estimate Kc by the NDVI, termed $\mathrm{Kc}_{\mathrm{NDVI}}$.

$$
\mathrm{y}=\mathrm{a}_{0}+\mathrm{b}_{\mathrm{i}} \mathrm{x}_{\mathrm{i}}(10)
$$

where $y$ is the dependent variable, $\mathrm{Kc}_{\mathrm{FAO}}$; $\mathrm{xi}$ is the independent variable, $\mathrm{NDVI}_{\text {mean }}$; and $\mathrm{a}_{0}$ and $b_{i}$ are the adjusted regression coefficients of the linear model.

Subsequently, the $\mathrm{Kc}_{\mathrm{NDVI}}$ (Equation 10) was calculated for each day of the year (DOY) in the different bands of the center pivots. It is important to mention that this approach was chosen because different sowing dates were adopted for the different orientations of the center pivots.

For a better understanding of the results, as well as the descriptive statistics, graphs were developed using $\mathrm{R}$ software ( $\mathrm{R}$ Core Team [R], 2016).

\section{Results and Discussion}

Table 2 shows the values of the meteorological variables measured on the dates the Landsat8 satellite images were acquired. During the phenological cycle, relative humidity $(\mathrm{RH})$ showed an amplitude of $35.6 \%$. The highest $\mathrm{RH}$ (67.2\%) was observed at 103 DOY, which coincided with the beginning of the phenological cycle for center pivots P25 and P26, whose plants were sown on April 4th and 5th, 2014, in the North position and April 3 and 4, 2014, in the South position, respectively. For the other center pivots, however, the maize had not yet been sown. 
Table 2

Climatic variables on the days of acquisition of the Landsat-8 images

\begin{tabular}{ccccccc|}
\hline & Tmax & Tmin & $\mathrm{RH}$ & $\mathrm{U}_{2}$ & $\mathrm{RG}$ & $\mathrm{ET}_{\circ}$ \\
\cline { 2 - 7 } & ${ }^{\circ} \mathrm{C}$ & ${ }^{\circ} \mathrm{C}$ & $\%$ & $\mathrm{~m} \mathrm{~s}^{-1}$ & $\mathrm{~W} \mathrm{~m}^{-2}$ & $\mathrm{~mm} \mathrm{~d}^{-1}$ \\
\hline 103 & 34.1 & 19.8 & 67.2 & 0.5 & 262 & 4.60 \\
135 & 33.6 & 17.9 & 51.5 & 0.5 & 230 & 4.04 \\
151 & 32.4 & 19.7 & 51.0 & 1.0 & 213 & 4.18 \\
183 & 35.7 & 19.7 & 40.4 & 0.7 & 215 & 4.14 \\
199 & 32.8 & 17.9 & 45.5 & 0.6 & 206 & 3.75 \\
231 & 31.1 & 17.2 & 38.7 & 1.7 & 255 & 5.86 \\
\hline 247 & 37.4 & 18.9 & 31.6 & 0.8 & 260 & 6.10 \\
\hline 263 & 39.5 & 22.9 & 32.1 & 1.1 & 282 & 7.62 \\
\hline Amplitude & 8.4 & 5.7 & 35.6 & 1.2 & 69 & 3.87 \\
\hline
\end{tabular}

DOY: day of the year; Tmax: maximum temperature; Tmin: minimum temperature; $\mathrm{RH}$ : relative humidity; $\mathrm{U}_{2}$ : wind speed at $2 \mathrm{~m}$ of height; $\mathrm{R}_{\mathrm{G}}$ : incident solar radiation; $\mathrm{ET}_{0}$ : reference evapotranspiration.

The highest values of maximum and minimum temperature, ETo and RG were recorded at 263 DOY, which refers to the senescence period of the crop for pivots $\mathrm{P} 21$, P22, P23 and P24; and exposed soil for the other center pivots, as the maize had already been harvested. On that date, because it was the senescence period, there was no irrigation in the area. Reference evapotranspiration was highest because the meteorological variables were decisive for its estimate, with incident solar radiation $\left(282 \mathrm{~W} \mathrm{~m}^{-2}\right)$ being the parameter of greatest influence (Pandey, Dabral, \& Pandey, 2016). The highest RH and the lowest $U_{2}$ occurred at 103 and 135 DOY. At 103 DOY, sowing had been only carried out under pivots 25 and 26, whose plants were at around nine days after sowing (DAS), whereas at 135 DOY the plants were at approximately 45 DAS for P23 North and P24. For the other pivots, the plants were at 25 DAS.
Table 3 shows the biophysical parameters throughout the irrigated maize cultivation cycle, for the different center pivots. The variables of $\alpha_{s^{\prime}} N D V I$ and $T_{s}$ are results of the status of the agroecosystems and allow the management of the crop to be directed to the more critical regions, generating significant gains to the production system (Ribeiro et al., 2017; Teixeira \& Leivas, 2017). The highest mean $\alpha$ s (0.19 to 0.25 ) and Ts (35.15 to 39.65 $\left.{ }^{\circ} \mathrm{C}\right)$ occurred before sowing and after 168 DAS. These high values are due to the presence of exposed soil and the senescence of the crops; thus, evapotranspiration is reduced and the sensitive heat is greater at the expense of the reduction in latent heat of vaporization. 
Table 3

Mean daily values and standard deviation of surface albedo $\left(\alpha_{s}\right)$, NDVI and surface temperature $\left(T_{s}\right)$ on the different days after sowing (DAS) in irrigated maize

\begin{tabular}{|c|c|c|c|c|c|c|c|}
\hline DAS & $\alpha_{s}$ & NDVI & $\mathrm{T}_{\mathrm{s}}$ & DAS & $\alpha_{s}$ & NDVI & $\mathrm{T}_{\mathrm{s}}$ \\
\hline \multicolumn{4}{|c|}{ Center Pivot 21 - North } & \multicolumn{4}{|c|}{ Center Pivot 21 - South } \\
\hline $\mathrm{BS}^{*}$ & $0.19 \pm 0.0020$ & $0.31 \pm 0.0070$ & $33.75 \pm 0.50$ & $\mathrm{BS}^{*}$ & $0.18 \pm 0.0015$ & $0.31 \pm 0.0101$ & $32.75 \pm 0.55$ \\
\hline 21 & $0.14 \pm 0.0053$ & $0.50 \pm 0.0161$ & $28.85 \pm 1.26$ & 22 & $0.14 \pm 0.0021$ & $0.52 \pm 0.0162$ & $27.85 \pm 0.81$ \\
\hline 37 & $0.12 \pm 0.0005$ & $0.79 \pm 0.0053$ & $21.25 \pm 0.16$ & 38 & $0.12 \pm 0.0038$ & $0.71 \pm 0.0102$ & $20.95 \pm 0.30$ \\
\hline 69 & $0.12 \pm 0.0009$ & $0.92 \pm 0.0032$ & $24.15 \pm 0.22$ & 80 & $0.12 \pm 0.0019$ & $0.92 \pm 0.0075$ & $24.25 \pm 0.41$ \\
\hline 85 & $0.13 \pm 0.0009$ & $0.90 \pm 0.0023$ & $20.95 \pm 0.21$ & 86 & $0.13 \pm 0.0019$ & $0.90 \pm 0.0085$ & $20.75 \pm 0.28$ \\
\hline 111 & $0.13 \pm 0.0011$ & $0.85 \pm 0.0075$ & $24.85 \pm 0.25$ & 112 & $0.13 \pm 0.0027$ & $0.85 \pm 0.0172$ & $24.75 \pm 0.42$ \\
\hline 127 & $0.13 \pm 0.0021$ & $0.61 \pm 0.0293$ & $30.35 \pm 0.19$ & 128 & $0.14 \pm 0.0040$ & $0.63 \pm 0.0572$ & $29.15 \pm 0.40$ \\
\hline 143 & $0.17 \pm 0.0022$ & $0.38 \pm 0.0044$ & $34.25 \pm 0.22$ & 144 & $0.16 \pm 0.0030$ & $0.38 \pm 0.0141$ & $34.05 \pm 0.29$ \\
\hline \multicolumn{4}{|c|}{ Center Pivot 22 - North } & \multicolumn{4}{|c|}{ Center Pivot 22 - South } \\
\hline $\mathrm{BS}^{*}$ & $0.19 \pm 0.0020$ & $0.32 \pm 0.0131$ & $34.15 \pm 0.59$ & $\mathrm{BS}^{*}$ & $0.19 \pm 0.0020$ & $0.33 \pm 0.0171$ & $33.75 \pm 0.54$ \\
\hline 19 & $0.15 \pm 0.0017$ & $0.45 \pm 0.0152$ & $28.75 \pm 0.67$ & 20 & $0.14 \pm 0.0050$ & $0.48 \pm 0.0202$ & $30.75 \pm 2.15$ \\
\hline 35 & $0.13 \pm 0.0010$ & $0.61 \pm 0.0104$ & $21.65 \pm 0.43$ & 36 & $0.12 \pm 0.0008$ & $0.59 \pm 0.0052$ & $21.05 \pm 0.30$ \\
\hline 67 & $0.12 \pm 0.0007$ & $0.91 \pm 0.0032$ & $24.35 \pm 0.51$ & 68 & $0.12 \pm 0.0007$ & $0.92 \pm 0.0021$ & $24.25 \pm 0.41$ \\
\hline 83 & $0.13 \pm 0.0010$ & $0.90 \pm 0.0031$ & $21.25 \pm 0.35$ & 84 & $0.12 \pm 0.0009$ & $0.90 \pm 0.0035$ & $21.05 \pm 0.29$ \\
\hline 115 & $0.14 \pm 0.0011$ & $0.85 \pm 0.0073$ & $24.95 \pm 0.59$ & 116 & $0.13 \pm 0.0011$ & $0.86 \pm 0.0041$ & $25.05 \pm 0.45$ \\
\hline 131 & $0.15 \pm 0.0022$ & $0.51 \pm 0.0401$ & $30.45 \pm 0.36$ & 132 & $0.15 \pm 0.0018$ & $0.66 \pm 0.0311$ & $30.35 \pm 0.28$ \\
\hline 147 & $0.16 \pm 0.0020$ & $0.38 \pm 0.0081$ & $34.65 \pm 0.32$ & 148 & $0.15 \pm 0.0019$ & $0.38 \pm 0.0032$ & $30.05 \pm 0.23$ \\
\hline \multicolumn{4}{|c|}{ Center Pivot 23 - North } & \multicolumn{4}{|c|}{ Center Pivot 23 - South } \\
\hline $\mathrm{BS}^{*}$ & $0.18 \pm 0.0042$ & $0.31 \pm 0.0123$ & $33.85 \pm 0.58$ & $\mathrm{BS}^{*}$ & $0.15 \pm 0.0$ & $0.33 \pm 0.0243$ & $55 \pm 0.43$ \\
\hline 28 & $0.13 \pm 0.0021$ & $0.54 \pm 0.0412$ & $26.45 \pm 0.45$ & 22 & $0.13 \pm 0.0026$ & $0.49 \pm 0.0212$ & $27.45 \pm 0.43$ \\
\hline 44 & $0.12 \pm 0.0012$ & $0.87 \pm 0.0072$ & $20.85 \pm 0.26$ & 38 & $0.12 \pm 0.0007$ & $0.80 \pm 0.0051$ & $21.05 \pm 0.23$ \\
\hline 76 & $0.12 \pm 0.0010$ & $0.92 \pm 0.0041$ & $24.35 \pm 0.43$ & 70 & $0.12 \pm 0.0010$ & $0.92 \pm 0.0024$ & $24.35 \pm 0.34$ \\
\hline 92 & $0.13 \pm 0.0012$ & $0.89 \pm 0.0034$ & $24.85 \pm 0.33$ & 86 & $0.13 \pm 0.0011$ & $0.89 \pm 0.0024$ & $20.55 \pm 0.29$ \\
\hline 124 & $0.15 \pm 0.0023$ & $0.79 \pm 0.0401$ & $26.25 \pm 0.51$ & 118 & $0.15 \pm 0.0045$ & $0.76 \pm 0.0691$ & $26.65 \pm 0.73$ \\
\hline 140 & $0.15 \pm 0.0044$ & $0.49 \pm 0.0244$ & $31.45 \pm 0.35$ & 134 & $0.15 \pm 0.0055$ & $0.49 \pm 0.0483$ & $31.55 \pm 0.45$ \\
\hline 156 & $0.16 \pm 0.0061$ & $0.35 \pm 0.0082$ & $35.55 \pm 0.31$ & 150 & $0.17 \pm 0.0045$ & $0.34 \pm 0.0091$ & $35.45 \pm 0.30$ \\
\hline \multicolumn{4}{|c|}{ Center Pivot 24 - West } & \multicolumn{4}{|c|}{ Center Pivot 24 - East } \\
\hline $\mathrm{BS}^{*}$ & $0.18 \pm 0.0035$ & $0.15 \pm 0.0031$ & $34.05 \pm 0.45$ & $\mathrm{BS}^{*}$ & $0.18 \pm 0.0022$ & $0.16 \pm 0.0022$ & $34.05 \pm 0.51$ \\
\hline 29 & $0.12 \pm 0.0011$ & $0.53 \pm 0.0123$ & $24.65 \pm 0.30$ & 31 & $0.12 \pm 0.0014$ & $0.38 \pm 0.0203$ & $24.45 \pm 0.21$ \\
\hline 45 & $0.12 \pm 0.0010$ & $0.68 \pm 0.0054$ & $20.25 \pm 0.18$ & 47 & $0.12 \pm 0.0009$ & $0.58 \pm 0.0043$ & $20.45 \pm 0.21$ \\
\hline 77 & $0.12 \pm 0.0010$ & $0.92 \pm 0.0032$ & $24.25 \pm 0.25$ & 79 & $0.12 \pm 0.0008$ & $0.92 \pm 0.0021$ & $24.05 \pm 0.28$ \\
\hline 93 & $0.13 \pm 0.0020$ & $0.89 \pm 0.0042$ & $21.05 \pm 0.25$ & 95 & $0.12 \pm 0.0013$ & $0.89 \pm 0.0025$ & $20.85 \pm 0.18$ \\
\hline 125 & $0.14 \pm 0.0036$ & $0.78 \pm 0.0671$ & $27.45 \pm 0.51$ & 127 & $0.14 \pm 0.0022$ & $0.76 \pm 0.0521$ & $26.45 \pm 0.32$ \\
\hline 141 & $0.15 \pm 0.0041$ & $0.40 \pm 0.0201$ & $31.45 \pm 0.18$ & 143 & $0.16 \pm 0.0021$ & $0.46 \pm 0.0182$ & $31.15 \pm 0.20$ \\
\hline 157 & $0.17 \pm 0.0078$ & $0.34 \pm 0.0135$ & $35.05 \pm 0.26$ & 159 & $0.17 \pm 0.0038$ & $0.35 \pm 0.0051$ & $34.55 \pm 0.20$ \\
\hline
\end{tabular}

continue... 
contuation...

\begin{tabular}{|cccccccc|}
\hline \multicolumn{5}{c}{ Center Pivot 25 - North } & \multicolumn{4}{c|}{ Center Pivot 25 - South } \\
\hline 9 & $0.16 \pm 0.0026$ & $0.37 \pm 0.0341$ & $32.25 \pm 0.58$ & 10 & $0.16 \pm 0.0029$ & $0.34 \pm 0.0164$ & $31.85 \pm 0.44$ \\
\hline 41 & $0.12 \pm 0.0010$ & $0.79 \pm 0.0112$ & $23.85 \pm 0.33$ & 42 & $0.12 \pm 0.0007$ & $0.53 \pm 0.0043$ & $23.55 \pm 0.29$ \\
\hline 57 & $0.12 \pm 0.0008$ & $0.89 \pm 0.0062$ & $20.65 \pm 0.24$ & 58 & $0.12 \pm 0.0009$ & $0.88 \pm 0.0043$ & $20.75 \pm 0.28$ \\
\hline 89 & $0.12 \pm 0.0010$ & $0.90 \pm 0.0103$ & $24.35 \pm 0.43$ & 90 & $0.12 \pm 0.0012$ & $0.90 \pm 0.0052$ & $24.55 \pm 0.37$ \\
\hline 105 & $0.14 \pm 0.0021$ & $0.86 \pm 0.0154$ & $20.55 \pm 0.54$ & 106 & $0.14 \pm 0.0210$ & $0.89 \pm 0.0111$ & $21.55 \pm 0.32$ \\
137 & $0.14 \pm 0.0032$ & $0.40 \pm 0.0444$ & $28.45 \pm 0.32$ & 138 & $0.14 \pm 0.0039$ & $0.42 \pm 0.0233$ & $28.65 \pm 0.32$ \\
\hline 153 & $0.15 \pm 0.0035$ & $0.32 \pm 0.0123$ & $31.85 \pm 0.27$ & 154 & $0.14 \pm 0.0045$ & $0.40 \pm 0.0123$ & $31.95 \pm 0.19$ \\
\hline 169 & $0.24 \pm 0.0067$ & $0.26 \pm 0.0094$ & $35.15 \pm 1.80$ & 170 & $0.25 \pm 0.0073$ & $0.24 \pm 0.0114$ & $37.75 \pm 2.03$ \\
\hline \multicolumn{4}{c}{ Center Pivot 26- North } & & & Center Pivot $26-$ South \\
\hline 8 & $0.16 \pm 0.0030$ & $0.30 \pm 0.0133$ & $32.65 \pm 0.70$ & 9 & $0.16 \pm 0.0028$ & $0.31 \pm 0.0062$ & $33.05 \pm 0.69$ \\
\hline 40 & $0.12 \pm 0.0011$ & $0.40 \pm 0.0083$ & $23.95 \pm 0.37$ & 41 & $0.12 \pm 0.0008$ & $0.46 \pm 0.0041$ & $24.05 \pm 0.46$ \\
\hline 56 & $0.12 \pm 0.0009$ & $0.88 \pm 0.0061$ & $20.55 \pm 0.48$ & 57 & $0.12 \pm 0.0010$ & $0.88 \pm 0.0031$ & $20.15 \pm 0.36$ \\
\hline 88 & $0.12 \pm 0.0013$ & $0.92 \pm 0.0041$ & $24.65 \pm 0.59$ & 89 & $0.12 \pm 0.0014$ & $0.91 \pm 0.0034$ & $24.55 \pm 0.39$ \\
\hline 104 & $0.14 \pm 0.0018$ & $0.86 \pm 0.0072$ & $21.55 \pm 0.36$ & 105 & $0.14 \pm 0.0020$ & $0.86 \pm 0.0074$ & $21.55 \pm 0.27$ \\
\hline 136 & $0.15 \pm 0.0035$ & $0.41 \pm 0.0323$ & $29.85 \pm 0.23$ & 137 & $0.14 \pm 0.0042$ & $0.48 \pm 0.0401$ & $29.55 \pm 0.35$ \\
\hline 152 & $0.19 \pm 0.0028$ & $0.39 \pm 0.0134$ & $32.45 \pm 0.21$ & 153 & $0.19 \pm 0.0059$ & $0.41 \pm 0.0142$ & $32.50 \pm 0.28$ \\
\hline 168 & $0.25 \pm 0.0044$ & $0.24 \pm 0.0121$ & $39.65 \pm 0.49$ & 169 & $0.25 \pm 0.0071$ & $0.25 \pm 0.0172$ & $39.55 \pm 0.49$ \\
\hline
\end{tabular}

*BS: before sowing.

Between 8 and 10 DAS, which corresponds to the emergence of the first leaf (VE and V1), referring to pivots P25 and P26 North and South, $\alpha_{s}$ was 0.16 , whereas the other center pivots showed values around 0.13 to from 19 DAS. This is because the plant increases leaf density and soil moisture tends to be preserved (Table 3). Sá, Sobrinho, Silva, Ferreira and Moura (2016) pointed out that albedo is very sensitive and can be influenced by the moisture conditions of the soil and plant, humidity, irrigation, land use and the presence of clouds. In areas of irrigated agriculture in the municipality of Jaíba-MG, Brazil, Veloso, Ferreira, Rosa and Silva. (2015) found mean $\alpha_{s}$ values of the orders of 0.15 and 0.21 in the crop development period and at harvest, respectively. These values are closely linked to the dynamics of land use in agricultural areas. In contrast, Sá et al. (2016) analyzed the mean daily albedo in the sprouting and emergence phase of the sugarcane crop and observed that the lowest daily mean $\alpha_{\mathrm{s}}$ value was 0.12 , considering the high absorption of solar energy, given that the soil had a low biomass density.

The electromagnetic radiation absorbed by plants is known to increase during the period of high vegetative development, due to the peak of photosynthesis. In other words, $\alpha_{s}$ decreases due to the greater use of incident energy, be it for the processes of photosynthesis or transpiration (Silva, Moura, Giongo, \& Silva, 2011). Then, when the plant reduces the photosynthetic rate, $\alpha_{s}$ increases again. 
Throughout the crop development cycle, NDVI showed variations, with a constant increase in the mean. This is explained by the fact that this index grows with the development of the crop, having reached its maximum value around 78 DAS and starting to decline from this point until the senescence of the crop and harvest (Table 3 ), as the nutrients are displaced for the development of reproductive organs. Subsequently, with maturation, the plant ceases to grow (Alface et al., 2019; Santos et al., 2020). To some extent, NDVI has a positive correlation with biomass gain. However, in the period of high biomass production there is a rapid saturation in the red band. As a consequence, the correlation between NDVI and the leaf area index (LAl) is not so strong in this situation, and so the increase in biomass can no longer be accompanied by the increase in the index values (Jensen, Bryan, Friedman, Henderson, Holz, 1983; Ponzoni \& Shimabukuro, 2007).

At the beginning of the crop's phenological cycle, when the soil was exposed, NDVI values were low, ranging from 0.30 to 0.37 . Toureiro, Serralheiro, Shahidian and Sousa. (2017) studied the irrigation requirement of maize grown in Mediterranean climatic conditions and found NDVI values close to 0.20 at 10 DAS, in contrast to the 0.34 and 0.37 found in the present study for P25 North and South. This difference in NDVI values is mainly related to the type of soil, amount of soil and straw present in the area. These authors also emphasized on the ability to perform irrigation management based on NDVI.

As also shown in Table 3, the days of higher Ts were also those with the highest RG and air temperature values (Table 2), which coincided with the beginning and end of the crop cycle. This indicates that the plant cover and the water content in the soil and in the plant have an influence on air temperature. In addition, the vegetative canopy is altered by $R_{G}$.

In terms of magnitude, $T_{s}$ tends to show a behavior inversely proportional to NDVI; i.e., lower $T_{s}$ values mean higher NDVI. It is worth mentioning that a high $\mathrm{T}_{\mathrm{s}}$ value indicates high canopy temperature and, as a consequence, the water content in the leaf is lower than necessary, indicating a possible condition of water stress (Bezerra, Moutra, Silva, Lopes, \& Silva, 2014). As stated by Toureiro et al. (2017), when subjected to the condition of water stress in the soil, the maize crop makes use of adaptive survival mechanisms, spending most of the day with the stomata partially closed. As a result, biomass production and grain yield are reduced.

Given that the phenological stage for the maize crop was characterized from the methodology proposed in the FAO-56 report (Allen et al., 1998) and in view of the sensitivity of NDVI to the presence of pigments that participate in photosynthetic and biomass processes in the aerial part (Formaggio \& Sanches, 2017; Ribeiro et al., 2017), we estimated the crop coefficient (Kc) from NDVI (Figure 2A). The equation was fitted based on the relationship between $\mathrm{NDVI}$ and $\mathrm{KC}_{\mathrm{FAO}}$ considering the area of the center pivots under study. The high coefficient of determination $\left(R^{2}=0.789\right)$ denotes that the variance in $\mathrm{Kc}_{\mathrm{FAO}}$ can be explained by NDVI. By analyzing the obtained p-value, it is possible to state that the fit was significant at $0.1 \%$ probability. Alface et al. (2019) reported a similar trend, with $\mathrm{R}^{2}=$ 0.71 , in an experiment estimating the KcNDVI of sugarcane in Mozambique. The authors stated that the spectral reflectance was able to provide a fast and accurate estimate of the Kc values. 
Figure 2B shows the mean values of $\mathrm{KC}_{\mathrm{FAO}}$ for the maize crop and $\mathrm{Kc}_{\mathrm{NDVI}}$ for all center pivots under study, for each image acquisition date. The mean $\mathrm{Kc}_{\mathrm{NDV}}$ values were estimated using the regression equation in Figure $2 \mathrm{~A}$. By comparing the behavior of the mean $\mathrm{Kc}_{\mathrm{FAO}}$ and $\mathrm{Kc}_{\mathrm{NDVI}}$ values (Figure 2B), we observe that $\mathrm{Kc}_{\mathrm{FAO}}$ showed a slightly higher trend than $\mathrm{KC}_{\mathrm{NDV}}$ in development stages III and IV. In stages I and II, however, it was lower than the $\mathrm{Kc}_{\mathrm{NDVI}}$ value estimated over time, with stages I, II, III and IV corresponding to $17 \%, 28 \%, 33 \%$ and $22 \%$, respectively, of the total cycle (Allen et al.,
1998). This demonstrates that the behavior of $\mathrm{KC}_{\mathrm{NDV}}$ is highly sensitive and directly influenced by aspects of the plant and ground cover. Statistical analysis revealed that it provided good performance, with low errors such as the root mean square error (RMSE $=0.099$ ) and the mean bias error $(\mathrm{BIAS}=0.001), \mathrm{R}^{2}=$ 0.85 and a correlation coefficient $(r)$ of 0.92 . It is noteworthy that the mean bias error shows the under- or overestimation of a model; in this respect, there was overestimation in this study.
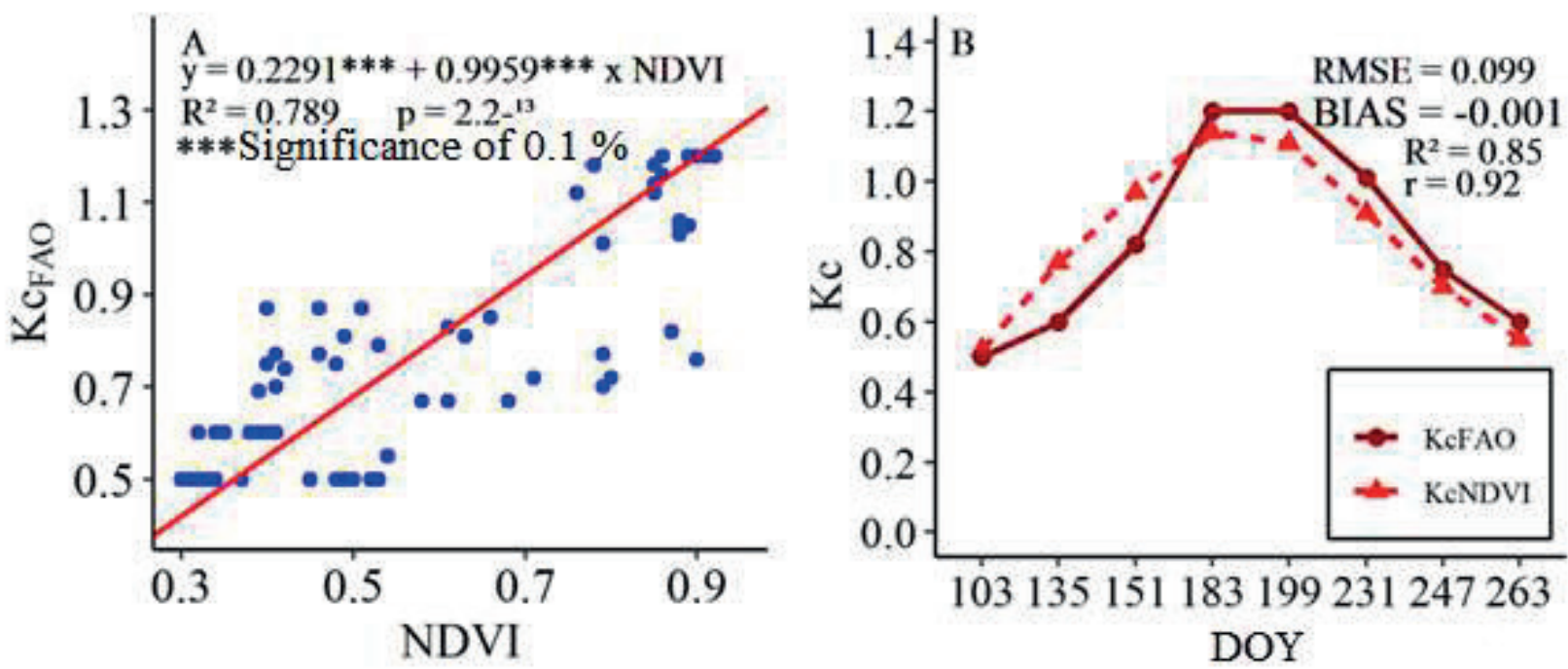

Figure 2. A: Adjusted linear regression between $\mathrm{Kc}_{\mathrm{FAO}}$ and NDVI values; $\mathrm{B}$ : Temporal behavior of the mean $\mathrm{Kc}_{\mathrm{FAO}}$ and $\mathrm{Kc}_{\mathrm{NDVI}}$ values of the maize crop. for the different center pivots and orientations. DOY: Day of the year in Julian.

The spatial and temporal values of ET, acquired by the SAFER algorithm indicate that $\mathrm{ET}_{\mathrm{c}}$ is influenced by climatic conditions, soil water content, above-ground biomass and leaf area (Frenck et al., 2018). The daily ET values are lower at the beginning of cultivation and increase from the stage of greater vegetative growth, tasseling and earing, in maize. Thereafter, they decrease when the plant reaches the physiological maturation stage and, subsequently, the physiological components die due to senescence (Figure 3).

Considering the center pivots with different planting dates (Table 1), the $\mathrm{ET}_{\mathrm{c}}$ 
pixel values ranged from 0.0 to $6.0 \mathrm{~mm} \mathrm{~d}^{-1}$ throughout the phenological cycle (Figure 4). The highest means were found for DOY 199, corresponding to around 100 DAS, which was because in this physiological stage the soil tends to always remain close to field capacity. In this way, the plants invest in intense photosynthesis, which increases stomatal opening. Additionally, the weather conditions also favored a greater $\mathrm{ET}_{\mathrm{c}}$. On this day, there was little variation in the $\mathrm{ET}_{\mathrm{c}}$ data, with the exception of center pivot P25 North, whose values ranged from 3.5 to $6.0 \mathrm{~mm} \mathrm{~d}^{-1}$. It is worth mentioning that this was the only area planted with cultivar Dekalb 390 Conventional maize, which has a super-early phenological cycle, with an average of 105 days. Another point to be highlighted is the occurrence of the maximum ETc for P26 (DOY 183, equivalent to 89 DAS).

The second highest mean $\mathrm{ET}_{\mathrm{c}}$ value (4.8 $\mathrm{mm} \mathrm{d}^{-1}$ ) occurred at 151 DOY, which corresponds to approximately 45 DAS and represents the period of greatest vegetative development in all center pivots (Figure 4).
Santos et al. (2020) described a similar result in an experiment in which the second-highest ETc identified in the seed maize crop was close to $5.0 \mathrm{~mm} \mathrm{~d}-1$, at 46 DAS. It should be noted that, at 231 DOY, center pivots P23 and P24 exhibited low uniformity in their area (Figure 3), with a greater range of data. Another noteworthy factor is the mean, which was less than the median for P23 and P24 East (Figure 4). This was possibly because sowing under these pivots was performed on different dates for different geographic orientations, which had a longer interval relative to the other pivots (P23 North sown on 04/17/2014, P23 South on $04 / 28 / 2014$, P24 West on $04 / 16 / 2014$ and P24 East on 04/09/2014). In addition, the low uniformity in each planting orientation can be explained by the fact that the cultivated areas vary in terms of type, texture and physical and water characteristics of the soil under the pivot orientations, as well as plant development. However, the irrigation amount is the same for the entire center pivot area. As a result, certain regions may have been under and/or over irrigated (Santos et al., 2020). 

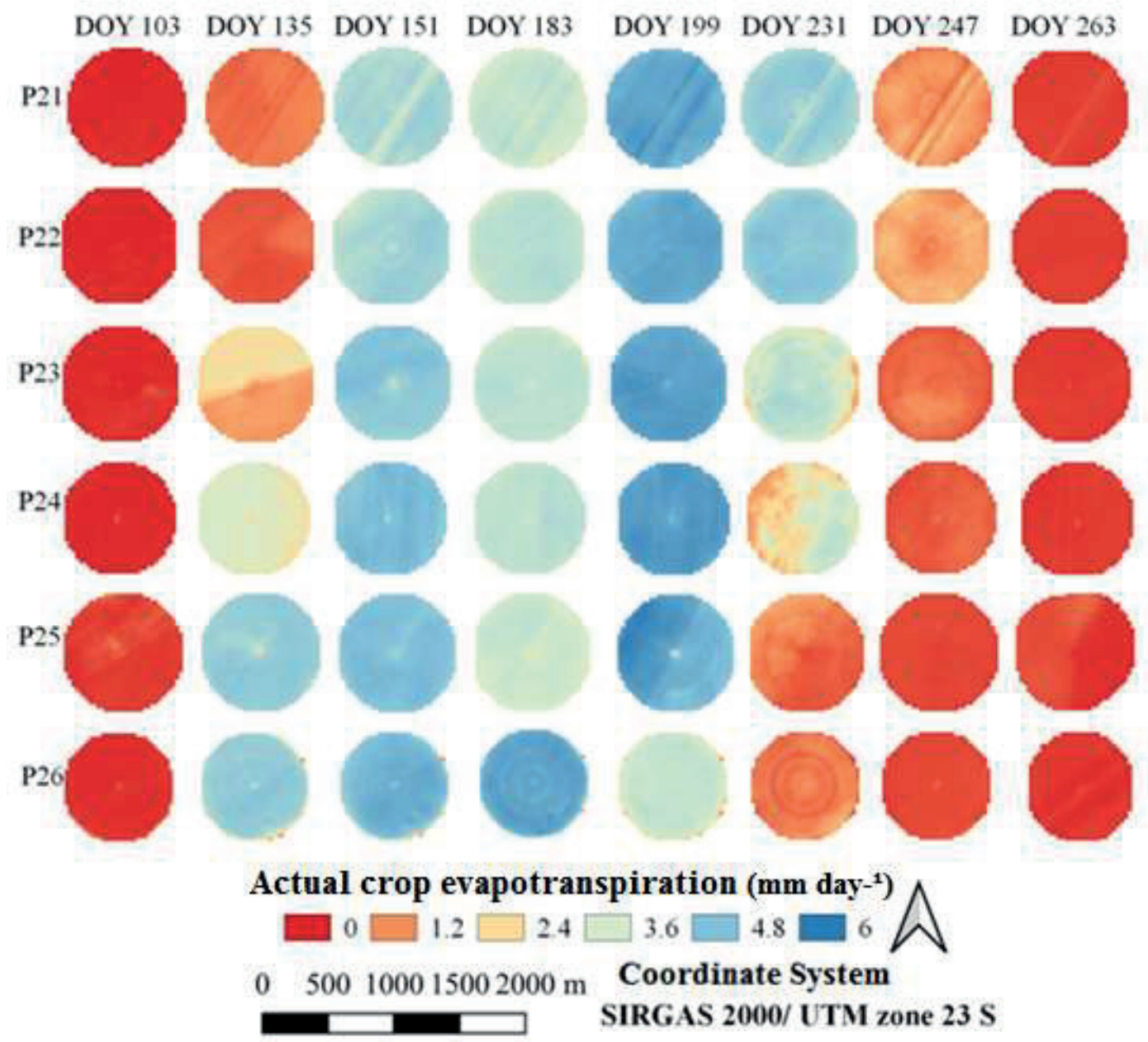

Figure 3. Spatial distribution of actual evapotranspiration (ETc) in the irrigated maize crop.

Figure 5 shows the spatial and temporal distribution of the biomass values accumulated in the maize crop (BIO) in kilograms per hectare, on the days the images were acquired. The $\mathrm{BIO}$ variable represents how much dry matter the plant incorporates per area, per day, in kilograms (Teixeira, Leivas, Andrade, \& Hernandez, 2015). 

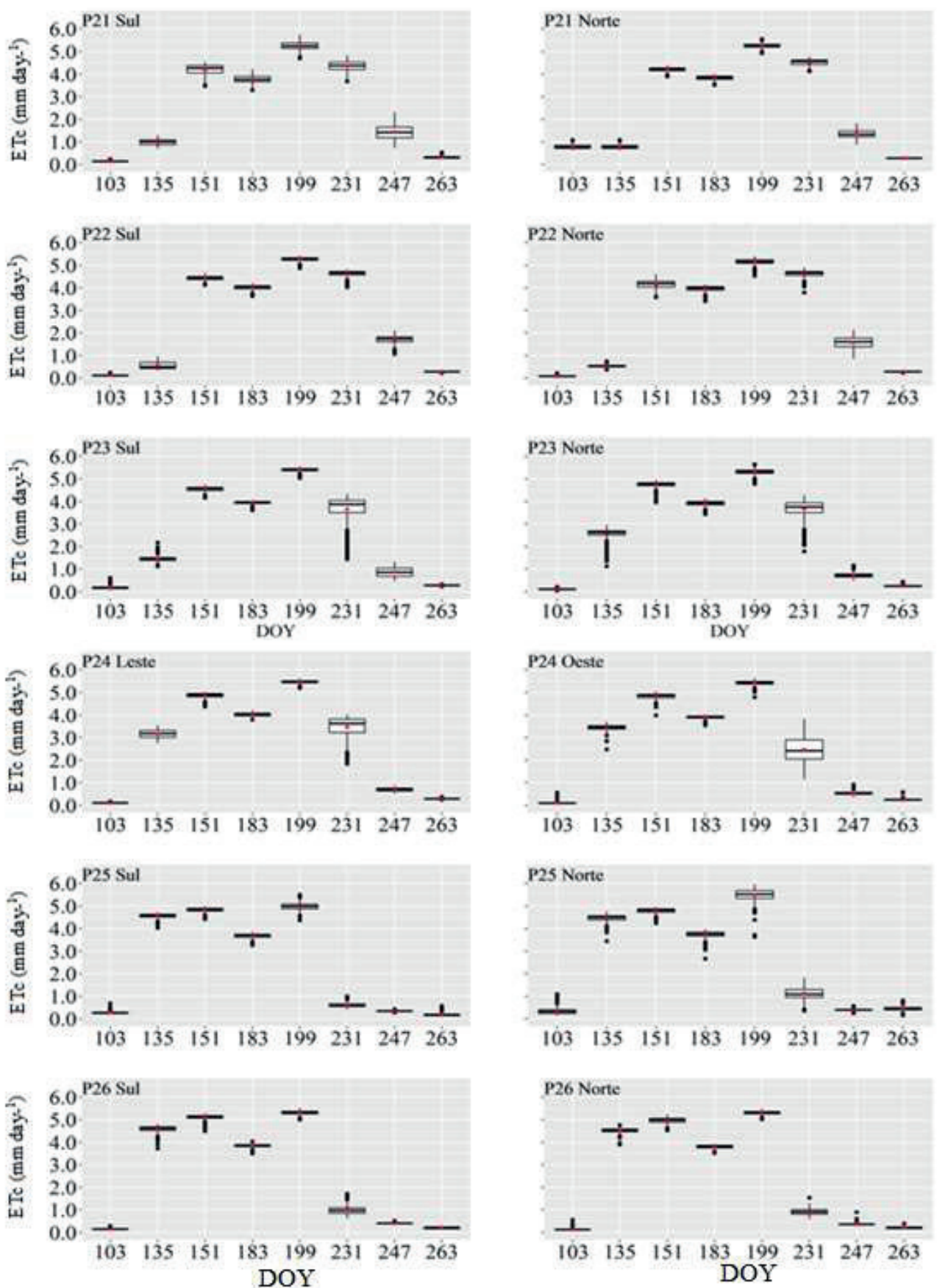

Figure 4. Boxplot of actual evapotranspiration (ET) of maize at different stages of development. obtained for the different orientations and center pivots. 


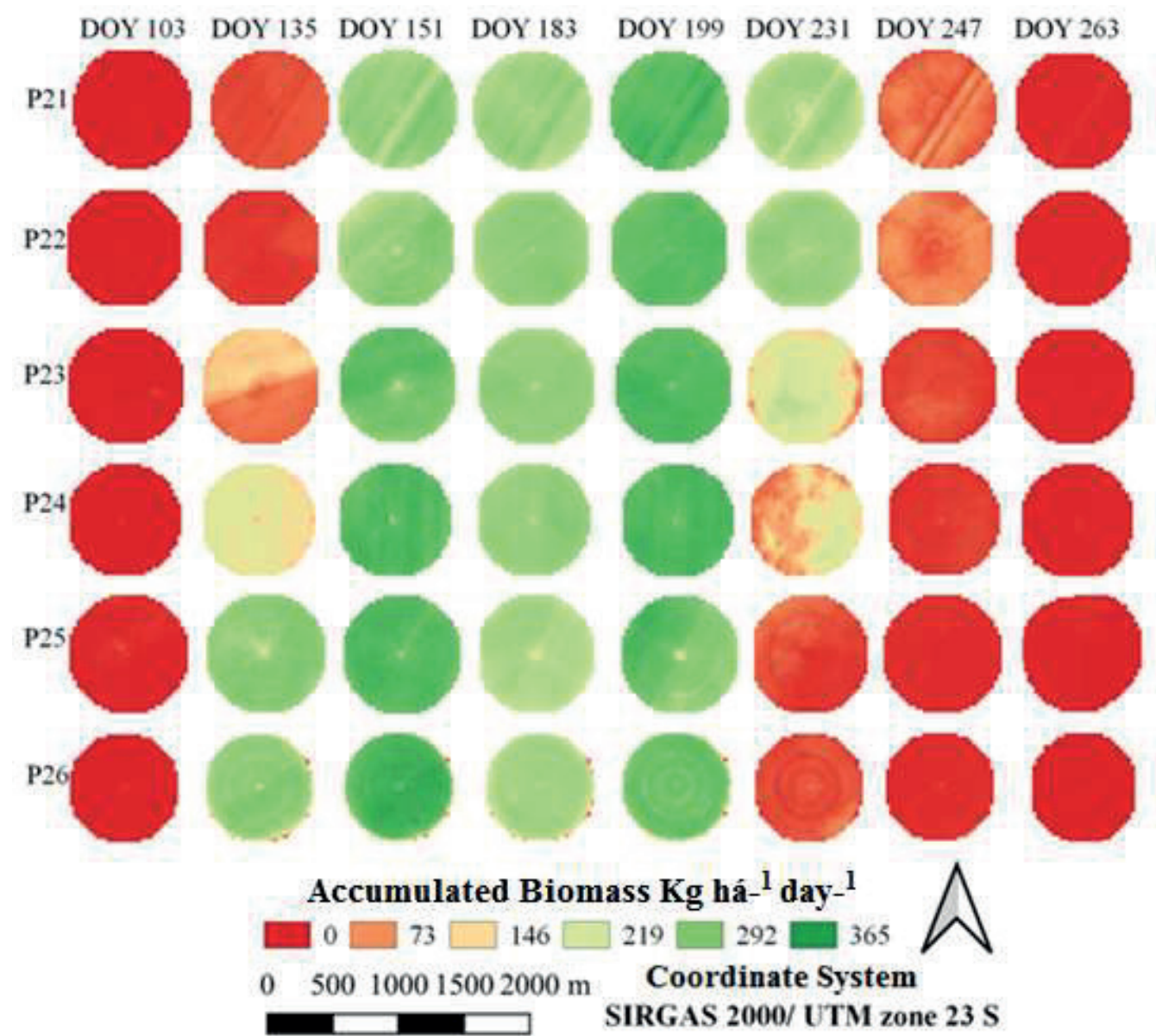

Figure 5. Spatial distribution of accumulated biomass $(\mathrm{BIO})$ in irrigated maize.

The lowest $\mathrm{BIO}$ values occurred at 135 DOY, around 20 DAS (Figure 6). On that date, the plants were in the phenological stage characterized by the interval between $\mathrm{V} 2$ and V3, when their photosynthetic activity is low due to the reduced leaf area, with mean values close to $45 \mathrm{~kg} \mathrm{ha}^{-1} \mathrm{~d}^{-1}$, as seen in center pivots P21 and P22. At 135 DOY, pivot P23 (Figure 6) showed a mean $\mathrm{BIO}$ of $50 \mathrm{~kg} \mathrm{ha}^{-1} \mathrm{~d}^{-1}$.

Analyzing all the boxplots together, it is clear that the highest $\mathrm{BIO}$ values were obtained precisely with the increase in plant development, which is also observed with the increasing NDVI and lower $\alpha_{\mathrm{s}}$ and $\mathrm{T}_{\mathrm{s}}$. This is because plants are more efficient in converting carbon and light in the photosynthetic system between 135 and 199 DOY, corresponding to 38 to 105 DAS, with values ranging from 220 to $345 \mathrm{~kg} \mathrm{ha}^{-1} \mathrm{~d}^{-1}$. After this period, BIO was drastically reduced due to the maturation and later senescence of maize, seen at 150 and 160 DAS, representing 247 and 263 DOY (Santos et al., 2020). The center pivots showed a mean very close to, or equal to the median, which indicates a database with normal behavior, except for P23 oriented South and P24 oriented East. These regions had a mean lower than the median and a greater dispersion of the data. 

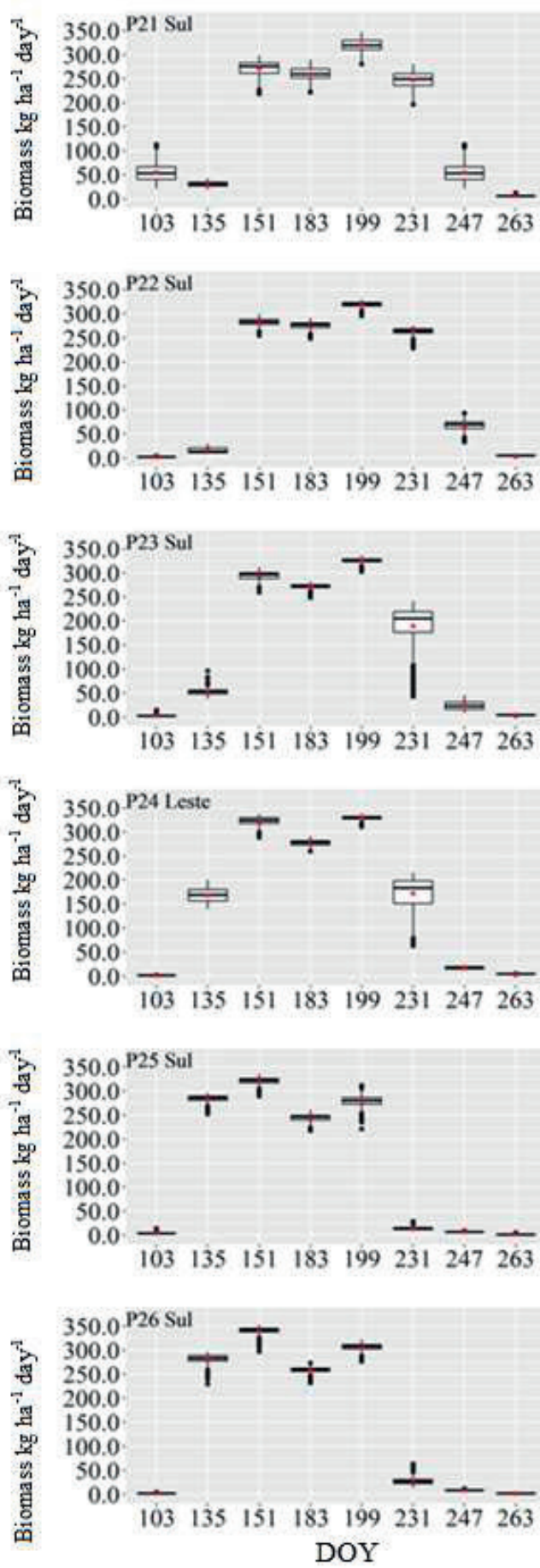
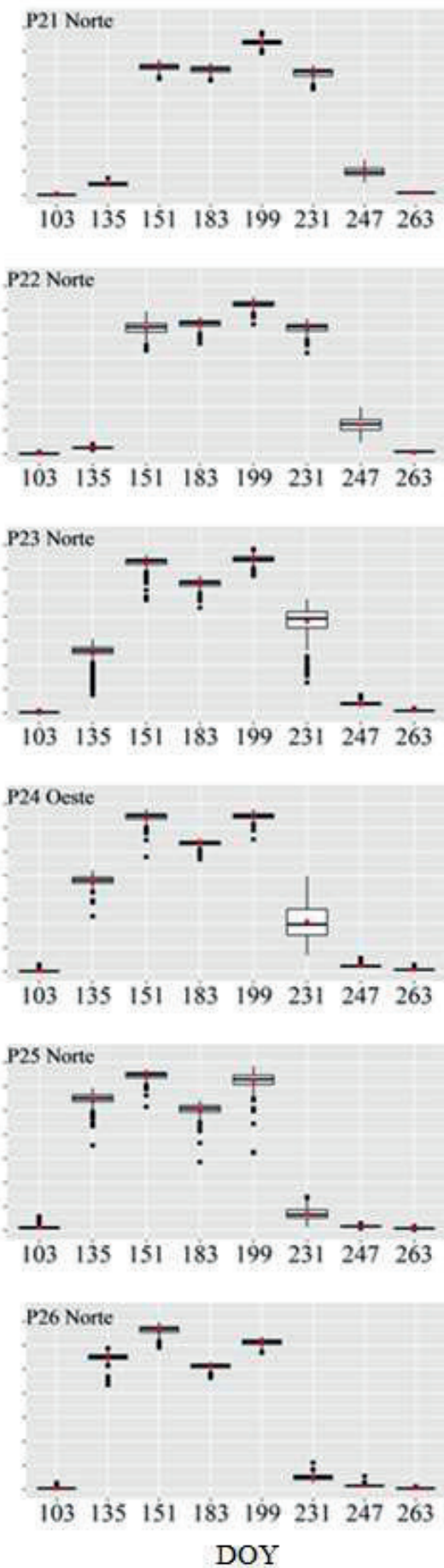

Figure 6. Boxplot of biomass $(\mathrm{BIO})$ of maize at different stages of development. obtained for the different orientations and center pivots. 
Because there is a relationship between $\mathrm{ET}_{\mathrm{c}}$ and $\mathrm{BIO}$, the DOY with the highest $\mathrm{BIO}$ values are equivalent to those with the highest $\mathrm{ET}_{\mathrm{c}}$ values (Yuan et al., 2013). In addition to this relationship, $\mathrm{BIO}$ is strongly influenced by water availability in the soil, with rainfed crops having higher $\mathrm{BIO}$ values during the rainy season and lower under drought conditions. In contrast, irrigated crops achieve higher $\mathrm{BIO}$ in the driest periods of the year, as the soils maintain their moisture close to field capacity, from the applied irrigation (Teixeira et al., 2015). However, in irrigated conditions, $\mathrm{BIO}$ is also influenced by high air temperature values and low incident solar radiation values (Bhuiyan, Saha, Bandyopadhyay, \& Kogan, 2017). In the Nilo Coelho irrigated perimeter, in the semiarid region of Brazil, Teixeira et al. (2015) found that the irrigated maize obtained $\mathrm{BIO}$ values twice as high as the species Alpinia purpurata in rainfed planting as reported by Wang, Ma, Huang, Veroustraete, Zhang, Song, \& Tan. (2012). This leads us to the conclusion that in the study of Teixeira et al. (2015), irrigation was the main factor responsible for the discrepancy in $\mathrm{BIO}$ values, besides plant physiology.

\section{Conclusions}

The use of remote sensing data from the SAFER algorithm was a relevant tool in the observation of biophysical processes throughout the crop cycle to determine $\mathrm{ET}_{\mathrm{c}}$. With the technique, it was possible to know the spatial-temporal dynamics of $\mathrm{ET}_{\mathrm{c}}$ in different physiological phases, indicating the possibility of identifying the irrigation volume to be applied in each location and stage of development of the crop, since the daily actual crop evapotranspiration rates can be dynamic in space and time.
When the plant is at its maximum dry matter increase, NDVI tends to be high. The daily dry matter increases observed in the area under study were similar to those described in studies with the same crop in irrigated areas.

The performance of the methodology used to estimate $\mathrm{Kc}_{\mathrm{NDV}}$ provided satisfactory and acceptable results when compared with $\mathrm{KC}_{\mathrm{FAO}}$ in maize. As such, it constitutes a great alternative to the tabulated values, with more representative values of $\mathrm{Kc}$ in space and with the real conditions throughout the crop cycle.

\section{Acknowledgements}

This study was carried out under the support of the Coordination for Improvement of Higher Education Personnel (CAPES) Brazil, under the Financing Code 001 and by the National Council for Scientific and Technological Development (CNPq).

\section{References}

Alface, A. B., Pereira, S. B., Filgueiras, R., \& Cunha, F. F. (2019). Sugarcane spatialtemporal monitoring and crop coefficient estimation through NDVI. Revista Brasileira de Engenharia Agrícola e Ambiental, 23(5), 330-335. doi: 10.1590/1807-1929/ agriambi

Allen, R. G., Pereira, L. S., Raes, D., \& Smith, M. (1998). Crop evapotranspiration guidelines for computing crop water requirements - FAO Irrigation and drainage paper 56 (9nd ed.). Rome: Food and Agriculture Organization of the United Nations. 
Althoff, D., Santos, R. A., Bazame, H, C., Cunha, F. F., \& Filgueiras, R. (2019). Improvement of hargreaves-samani reference evapotranspiration estimates with local calibration. Water, 11(11), 22-72. doi: 10. 3390/w11112272

Bastiaanssen, W. G. M., \& Ali, S. (2003). A new crop yield forecasting model based on satellite meas urements applied across the Indus Basin, Pakistan. Agriculture, Ecosystems e Environment, 94(3), 321-340. doi: 10.1016/S0167-8809(02)00034-8

Bernardo, S., Mantovani, E. C., Silva, D. D., \& Soares, A. A. (2019). Manual de irrigação (9a ed.). Viçosa, MG: Imprensa Universitária da UFV.

Bezerra, J. M., Moutra, G. B. A., Silva, B. B., Lopes, P. M. O., \& Silva, E. F. F. (2014). Parâmetros biofísicos obtidos por sensoriamento remoto em região semiárida do estado do Rio Grande do Norte, Brasil. Revista Brasileira de Engenharia Agrícola e Ambiental, 18(1), 73-84.

Bhuiyan, C., Saha, A. K., Bandyopadhyay, N., \& Kogan, F. N. (2017). Analyzing the impact of thermal stress on vegetation health and agricultural drought - a case study from Gujarat, India. Journal GIScience \& Remote Sensing, 54(5), 1943-7226. doi: 10.1080/15481603.2017.1309737

Congedo, L. (2016). Semi-automatic classification plugin documentation: release 5.0.1.1. Roma: Sapienza University of Rome.

Formaggio, A. R., \& Sanches, I. A. (2017). Sensoriamento remoto na agricultura. São Paulo: Oficina de Textos.
Frenck, G., Leitinger, G., Obojes, N., Hofmann, M., Newesely, C., Deutschmann, M.,... Tasser, E. (2018). Community-specific hydraulic conductance potential of soil water decomposed for two Alpine grasslands by small-scale lysimetry. Biogeosciences, 15(1), 1065-1078. doi: 10.5194/bg-15-1065-2018

Higuchi, N., Santos, J., Ribeiro, R. J., Minette, L., \& Biot, Y. (1998) Biomassa da parte aérea da vegetação de floresta tropical úmida de terra-firme da Amazônia Brasileira. Acta Amazônica, 28(1), 153-165. doi: 10.1590/1809-43921998282166

Jensen, J. R., Bryan, M. L., Friedman, S. Z., Henderson, F. M., Holz, R. K., Lindgren. D.,... Wray, J. R. (1983). Urban/suburban land use analysis. In J. E. Estes (Ed.), Manual of remote sensing (vol. 2, pp. 1571-1666, 2nd ed.). Falls Church, VA: American Society of Photogrammetry.

Martins, C. L., Busato, C., Silva, S. F., Rodrigues, W. N., \& Reis, E. F. (2013). Avaliação do desempenho de sistemas de irrigação no sul do Estado do Espírito Santo. RevistaAgro@mbiente, 7(2), 236-241. doi: 10.18227/1982-8470ragro.v7i2.1069

Monteith, J. L. (1972). Solar radiation and productivity in tropical ecosystems. Journal of Applied Ecology 9(3), 747-766. doi: $10.2307 / 2401901$

Pandey, P. K., Dabral, P. P., \& Pandey, V. (2016). Evaluationofreferenceevapotranspiration methods for the Northeastern region of India. International Soil and Water Conservation Research, 4(1), 56-67. doi: 10.1016/j.iswcr.2016.02.003 
Ponzoni, F. J., \& Shimabukuro, Y. E. (2007). Sensoriamento remoto no estudo da vegetação. São José dos Campos: Ed. Parêntese.

QGIS Development Team (2015). QGIS Geographic information system (3.16). Retcovered from http:// www.qgis.org/

$\mathrm{R}$ Core Team (2016). R: A language and environment for statistical computing. Vienna, Austria: R Foundation for Statistical Computing. Retrieved from https://www.R-project.org/

Ribeiro, R. B., Filgueiras, R., Ramos, M. C. A., Almeida, L. T., Generoso, T. N., \& Monteiro, L. I. B. (2017). Variação espacial-temporal da condição da vegetação na agricultura irrigada por meio de imagens sentinela. Revista Brasileira de Agricultura Irrigada, 11(1), 1884-1893. doi: 10.7127/rbai.v11 n600648

Rissini, A. L. L., Kawakami, J., Genú, A. M. (2015). Índice de vegetação por diferença normalizada e produtividade de cultivares de trigo submetidas a doses de nitrogênio. Revista Brasileira de Ciência do Solo, 39(6), 1703-1713. doi: 10.1590/01000683rbcs20140686

Rouse, J. W., Haas, R. H., Schell, J. A., \& Deering, D. W. (1974). Monitoring vegetation systems in the great plains with ERTS. Proceedings of the Earth Resources Technology Satellite-1, Symposium, Greenbelt, 3.

Sá, P. C. C., Sobrinho, J. S., Silva, S. T. A., Ferreira, R. C., \& Moura, M. S. B. (2016). Estimativa do saldo de radiação em cultivo irrigado de cana-de-açúcar utilizando dados de sensoriamento remoto orbital. Revista Brasileira de Geografia Física, 9(7), 21642178. doi: 10.5935/1984-2295.20160153
Santos, R. A., Venancio, L. P., Filgueiras, R., \& Cunha, F. F. (2020). Remote sensing as a tool to determine biophysical parameters of irrigated seed corn crop. Semina: Ciências Agrárias, 41(2), 435-446. doi: 10. 5433/1679-0359.2020v41n2p435

Silva, A. P. N., Moura, G. B. A., Giongo, P. R., \& Silva, B. B. (2011). Albedo de superfície estimado a partir de imagens Landsat 5 - TM no Semiárido Brasileiro. Revista de Geografia, 27(1), 154-168.

Silva, B. B., Braga, A. C., Braga, C. C., Oliveira, L. M. M., Montenegro, S. M. G., \& Barbosa, B., Jr. (2016). Procedures for calculation of the albedo with OLI-Landsat 8 images: application to the Brazilian semi-arid. Revista Brasileira de Engenharia Agrícola e Ambiental, 20(1), 3-8. doi: 10.1590/18071929

Teixeira, A. H. C. (2010). Determining regional actual evapotranspiration of irrigated and natural vegetation in the São Francisco riverbasin (Brazil) using remote sensingan Penman-Monteith equation. Remote Sensing, 2(5), 1287-1319. doi: 10.3390/ rs0251287

Teixeira, A. H. C., \& Leivas, J. F. (2017). Determinação da produtividade da água com imagens Landsat 8 na região Semiárida do Brasil. Revista Conexões Ciência e Tecnologia, 11(1), 22-34. doi: 10.21439/conexoes.v11i1.1064

Teixeira, A. H. C., Leivas, J. F., Andrade, R. G., \& Hernandez, F. B. T. (2015). Water productivity assessments with Landsat 8 images in the Nilo Coelho irrigation scheme. Revista Irriga, 1(2), 1-10. doi: 10.15809/irriga.2015v1n2p01 
Teixeira, A. H. C., Scherer-Warren, M., Hernandez, F. B., Andrade, R. G., \& Leivas, J. F. (2013). Large-scale water productivity assessments with modis images in a changing semi-arid environment: a brazilian case study. Remote Sensing, Multidisciplinary Digital Publishing Institute, 5(11), 5783-5804. doi: 10.3390/ rs5115783

Toureiro, C., Serralheiro, R., Shahidian, S., \& Sousa, A. (2017). Irrigation management with remote sensing: Evaluating irrigation requirement for maiz eunder Mediterranean climate condition. Agricultural Water Management, 184(1), 211-220. doi: 10.1016/j.agwat.2016.02. 010

United States Geological Survey (2015). Landsat Project Description. Recuperado de http://landsat.usgs.gov/about_project _descriptions.php.

Vanhellemont, Q., \& Ruddick, K. (2014). Turbid wakes associated with of shore wind turbines observed with landsat 8. Remote Sensing of Environment, 145(1), 105-115. doi: 10.1016/j.rse.2014.01.009
Veloso, G. A., Ferreira, M. E., Rosa, R., \& Silva, B. B. (2015). Determinação do albedo de superfície em áreas irrigadas do projeto Jaíba (Minas Gerais) mediante imagens Landsat 5 - TM. Revista R. Ra'eGa, 35(1), 126-146. doi: 10.5380/raega.v35i0.39757

Wang, X., Ma, M., Huang, G., Veroustraete, F., Zhang, Z., Song, Y., \& Tan, J. (2012). Vegetation primary production estimation at maize and alpine meadow over the Heihe River Basin, China. International Journal of Applied Earth Observation Geoinformation, 17(1), 94-101. doi: 10.10 16/j.agrformet.2018. 01.005

Yuan, M., Zhang, L., Gou, F., Su, Z., Spiertz, J. H. J., \& Van. W. W. (2013). Assessment of crop growth and water productivity for five C3 species in semi-arid Inner Mongolia. Agricultural Water Management, 122(5), 28-38. doi: 10.1016/j.agwat.2013.02.006 
